\title{
Some Remarks on Word Order and Information Structure in Romance and Greek
}

\author{
Artemis Alexiadou \\ Universität Potsdam \\ artemis@kronos.ling.uni-potsdam.de
}

\begin{abstract}
This paper is a preliminary comparative study of the relation between word order and information structure in three Null Subject Languages ((NSLs) Spanish, Italian and Greek). The aim is twofold: first I seek to examine the differences and the similarities among these languages in this domain of their syntax. Secon, I investigate the possible derivations of the various patterns and attempt to localize the differences among these languages in different underlying syntactic structures.
\end{abstract}

\section{Introduction}

In the literature on Romance (see e.g. the references in Zubizarreta 1998, Costa 1998) and on Greek (see the references in Alexiadou \& Anagnostopoulou to appear) it has been noted that the information structure of a given sentence is reflected in the manner in which phrases are structured in the sentence, and moreover that it is crucially related to its intonational structure. Thus languages such as Spanish, Italian, Portuguese and Greek have been argued to bear a certain resemblance to so called discourse configurational languages, as the different word order patterns convey different information.' I turn to a brief demonstration of this property below.

A basic fact about Romance and Greek is that postverbal subjects in these languages are not equivalent to preverbal subjects from the point of view of information structure, i.e. they tend to constitute 'new' information. Consider the Greek sentences in (1). Once the DP 'a letter' has been introduced in the discourse, i.e. it conveys 'old' information, it can no longer occupy a postverbal position:

(1) a. i Maria mu estile ena grama. to grama irthe simera Mary-nom me sent a letter-acc. the letter-nom arrived today

b. i Maria mu estile ena grama. \%irthe to grama simera Mary-nom me sent a letter-acc. arrived the letter-nom today

On the other hand, tests diagnosing the 'new' information status of a certain DP show that preverbal subjects are not acceptable in contexts where they convey 'new' information. For instance, standard answers to the question 'what happened?' in Greek involve inverted orders (see Alexiadou 1999 and references therein). In this case all information is new:

1 In this literature there are a number of discourse related notions that have been brought into the discussion: topic/comment, categorical/thetic judgements, old information/new information. 
- what happened?
a. espase o Janis ti lampa
broke-3sg John-nom the lamp-acc
'John broke the lamp'
b. *o Janis espase ti lampa
c. eftase ena grama apo to Parisi
arrived a letter-nom from Paris

If one considers that notions such as 'old' and 'new information' can be articulated with the grammatical notions of topic and focus which are grammatically encoded in sentence grammar, then preverbal subjects behave like topics, while postverbal subjects are part of the focus. On this view, VSO orders in Greek and Spanish can be referred to as all focused (see for instance the contributions in Kiss (1995) and the discussion in Zubizarreta (1998)).

With respect to the term focus, note that Rochemont (1986) and Kiss (1995) distinguish between two types of foci: contrastive focus which contrasts the subset of a set of alternatives with the complement subset and presentational/information focus which conveys only new information, as in (2) above. Others assimilate the two notions. It has been argued that phrases linked with contrastive focus generally involve exhaustivity readings and their special status is the result of an operator movement to a designated position. On the other hand, phrases associated with information focus remain in situ. As we will see in detail, word order in Greek crucially distinguishes between the two types in the sense that the example in (2a) above is associated with presentational focus only.

Interestingly, this difference in information structure briefly described above correlates with specific and different syntactic structures. Thus preverbal subjects in Greek and Spanish can be shown to occur in a sentence peripheral $\mathrm{A}^{\prime}$-position (see Contreras 1991, Barbosa 1994, Dobrovie-Sorin 1987, Alexiadou 1999, Alexiadou \& Anagnostopoulou 1998 among many others). They behave like Clitic Left Dislocated (CLLDed) elements directly merged in an $\mathrm{A}^{\prime}$-position. The reader is referred to the work of the aforementioned authors for discussion with respect to the $\mathrm{A}^{\prime}$-status of preverbal subjects and to Cardinaletti (1997) for arguments against this view. On the other hand, as has been argued in detail in Alexiadou (1999), Alexiadou \& Anagnostopoulou (1998) among others, postverbal subjects in languages such as Greek and Spanish remain VP internal, as opposed to VSO orders in Irish (see for instance McCloskey 1996). In other words, postverbal, i.e. focused, subjects remain in situ, while preverbal, i.e. topic, subjects occupy an A'-position. This in turn means that 'new' information subjects are located inside the VP, while 'old' information subjects are located outside the IP. This roughly corresponds to the positions often argued for in the literature to be occupied by 'new' and 'old' information DPs (see Diesing 1992, and Meinunger 1999 for references and extensive discussion).

However, it turns out that there are important differences with respect to the placement of subjects in the various NSLs both in the left periphery and in the postverbal domain, crucially interfering with information structure, which must be looked at more closely.

The paper is structured as follows. In section 2 I examine in detail the differences that exist among these three NSLs both in the preverbal and the postverbal domain. In section 3 I investigate the sensitivity of the word order patterns to the information structure pointing out again some differences among these languages, by paying special attention to the VOS order, the one inverted order shared by all the languages. Finally, in section 4 I turn to the syntactic analysis of VOS orders. In my discussion of the Greek facts I leave 
out examples involving clitic doubled objects for reasons of space (but see Alexiadou \& Anagnostopoulou 1999, 2000 for a preliminary discussion). Clearly, a detailed investigation of these phenomena should include these patterns as well.

\section{Differences in the Word Order Patterns of Spanish, Italian and Greek}

\subsection{Preverbal Domain}

While in Greek and Spanish, preverbal subjects can be shown to occupy an A'-position, the preverbal position in Spanish can contain phrases other than the subject, i.e. the subject competes with other elements for the preverbal position. Moreover, the verb is adjacent to the XP that precedes it (see Zubizarreta 1998):

(3) a. María presentó su renuncia ayer

Mary presented her resignation yesterday

b. ayer presentó María su renuncia

yesterday presented Mary her resignation

c. *Temprano Julia salia de casa

early Julia left home

(4) a. *LAS ESPINACAS Pedro trajo

the spinach Pedro brought

b. *algo donde encontraste?

something where you found

'Where did you find something'

As shown in (3c) and (4), the preverbal subject in Spanish competes with focus, emphatic, topic and wh-phrases for this fronted position. In this respect, Spanish resembles the Germanic languages, especially Icelandic and Yiddish. Thus the preverbal position in Spanish is not uniquely for CLLDed material.

In Greek, there is no such competition in the sense that the language permits multiple dislocations (cf. 5).

(5) a. O Petros htes meta apo poles prospathies sinandise ti Maria. Peter-nom yesterday after from many efforts met Mary-acc 'After many efforts, Peter met Mary yesterday'.

b. ti Maria kthes meta apo polles prospathies ti sinandise o Petros. Mary-acc yesterday after from many efforts cl-acc met Peter-nom 'After many efforts, Peter met Mary yesterday'.

Likewise, Italian permits multiple CLLDs (cf. Cinque 1990).

Moreover, focused consituents in Greek do not need to be adjacent to the verb, but may precede Topics (cf. (6a); Giannakidou 1997, contra Tsimpli 1995). Furthermore, 
preverbal subjects interfere with wh-movement in the following sense: ${ }^{2}$ subjects/CLLDed objects are not allowed to intervene between the wh-phrase and the Verb when the fronted element is a non D-linked argument (6d). Torrego (1984) and Canac Marquis (1991) analyse this as a Subjacency effect that Anagnostopoulou (1994) attributes to the status of preverbal subjects as CLLDed:

$$
\begin{aligned}
& \text { a. STON PAVLO ktes edose i Maria ta lefta } \\
& \text { to Paul yesterday gave-3sg Mary-nom the money- acc }
\end{aligned}
$$

'It was to Paul that Mary gave the money yesterday'

b. pjon apo tus fitites o Janis sinandise ktes who-acc from the students John-nom met-3sg yesterday

'Which one of the students did John meet yesterday'

c. Pjos apo tus fitites tin askisi tin elise who from the students the excersice-acc cl-acc solved-3sg amesos? immediately?

'Which one of the students solved the excersice immediately?'

d. Pjon ( ${ }^{o}$ o Petros) ide (o Petros)? whom Peter-nom saw Peter

Italian patterns like Greek with respect to focus, but not with respect to wh-movement. As shown in (7), a focus phrase can precede a topic phrase in Italian, but a wh-phrase, irrespectively of its D-linked character, cannot precede a topic phrase:
a. QUESTO Gianni ti dira
this John to you will tell
b. che cosa (*a Gianni) gli dovremmo dire what to John we should say (Rizzi 1997)

This perhaps may be attributed to the fact that the wh-criterion is operative in Italian, thus requiring strict verb-wh-phrase adjacency, but not in Greek (see Anagnostopoulou 1994 for detailed argumentation). On the other hand, Spanish seems to have a generalised $\mathrm{A}^{\prime}$-criterion, i.e. a well formedness condition which requires $\mathrm{A}^{\prime}$-elements to be in a specifier-head configuration with a head independently marked for this feature (along the lines suggested in Ortiz de Urbina 1995 for Basque).

Preverbal focus is always contrastive in all these languages. That is preverbal focused material is acceptable in a situation in which the presupposition is explicitly negated, as illustrated in (8) for Greek. Arguably such a configuration is derived by A'-movement to a focus projection, as argued for in detail in Tsimpli (1995):

$$
\begin{aligned}
& \text { O JANIS tha erthi (ohi o Kostas) } \\
& \text { John will come not Kostas }
\end{aligned}
$$

2 Note here that a similar restriction holds in Spanish. That is (6b-c) would be grammatical in Spanish as well. 
While in Greek and Spanish, the arguments for the $\mathrm{A}^{\prime}$-status of the preverbal subject seem to be rather convincing, in Italian there is no clear evidence that the preverbal subject is CLLDed (see the discussion in Cardinaletti 1997). For instance, Aux-to-Comp contexts, which disallow CLLDed material (9b), admit full subjects (9a):

(9) a. Avendo Gianni telefonato a Maria

Having John called Mary

b. *avendo a Roma vissuto per venti anni

having in Rome lived for twent years

Presumably the differences that exist between Italian and Greek are due to the different properties of left dislocation in the two languages (see Cinque 1990), namely bare quantified objects under a non-specific reading can be fronted in Italian, but not in Greek (see Anagnostopoulou 1999). As discussed in Cinque (1990:15), CLLD of bare quantifiers in Italian does not require a resumptive clitic:

Qualcuno, (lo) troveremo

someone we (him) will find

When the clitic is present the quantifier is interpreted as specific, when the clitic is absent the quantifier is interpreted as non-specific (see also Dobrovie-Sorin 1990 for Romanian).

These facts do not seem to hold in Greek. Bare quantifiers either undergo CLLD, in which case a clitic is required and the quantifiers are generally interpreted as specific, or they undergo focus-movement, in which case the clitic is necessarily absent (this is always the case with focus-movement in Greek, cf. Tsimpli 1995 for discussion and references):

(11) a. Kapjon i Maria *(ton) epjase na antighrafi

Someone, the Mary *(him) found-3sg to cheat

'Mary found somebody cheating'

b. *Kapjon tha vrume (alla den kserume pjon)

Someone will find-we (but we don't know whom)

'We'll find someone (but we don't know who)'

c. KAPJON tha vroume (alla den kseroume pjon)

someone fut find-1pl but neg know whom

Leaving focussed preverbal subjects aside, the structures below depict the positions preverbal subjects have been argued to occupy in the languages under consideration.

(12) a.
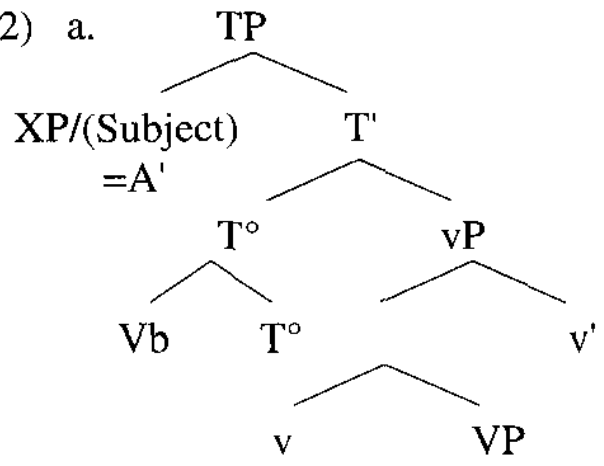

Spanish 


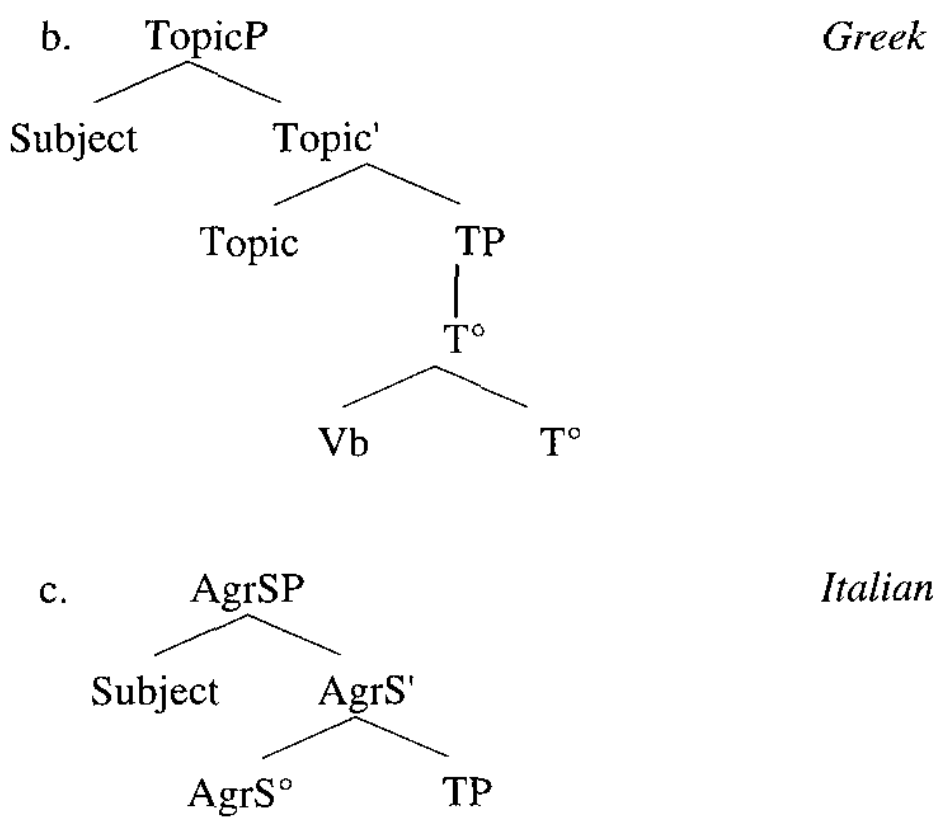

From the above structures it is clear that in Greek preverbal subjects occupy a CLLDed position. On the other hand, the preverbal position in Spanish seems to behave as a mixed category, given that other elements seem to be able to occupy it as well. Italian differs from both Spanish and Greek. Under Cardinaletti's analysis, the preverbal position in Italian can be but need not be CLLDed unlike in Greek. The essence of Cardinalett's proposal is that Italian behaves more like an SVO language of the English type. In other words, realised Subjects and Null Subjects (or perhaps null locatives see below) seem to be in competition. As we will see, this seems to correlate with the information structure associated with SVO orders in Italian.

In the next section I turn to the placement of subjects in the postverbal domain.

\subsection{Postverbal Domain}

As shown in (13) and (14), in Greek and Spanish postverbal subjects occur with all types of intransitives predicates: ${ }^{3}$

(13) a. efige o Petros.

unaccusative

left Peter-nom

Peter left.

b. epekse o Petros.

unergative

played Peter-nom

Peter played.

(14) a. se rio Juan

Spanish

laughed Juan

b. han estornudado tres leones

have sneezed three lions

3 As noted in Alexiadou (1996), with unergatives postverbal subjects are fully acceptable when the verb inflects for perfective Aspect. Imperfective marking gives less acceptable results. 
Both languages also permit postverbal subjects with all types of transitive predicates. Moreover, they both allow VSO and VOS orders:
a. ektise i Maria to spiti accomplishment built the Mary-nom the-house-acc 'Mary built the house'
b. kerdise i Maria ton agona won the-Mary-nom the-race-acc 'Mary won the race'

c. egrafe i Maria to grama olo to proi process wrote-imp:3sg the-Mary-nom the-letter-acc all the morning 'Mary was writing the letter the whole morning'

(16) a. ektise to spiti i Maria built the house-acc Mary-nom

b. kerdise ton agona i Maria won- 3 sg the race-acc Mary-nom

c. egrafe to grama i Maria olo to proi wrot-imp:3sg the letter-acc Mary-nom all the morning

(17) a. ayer presentó Marîa su renuncia yesterday presented Mary her resignation

b. me regaló la botella de vino María to me gave the bottle of wine Mary

The difference between Spanish and Greek VSO orders is that the former are licit, only when another XP occupies first position:

??(ayer) presentó María su renuncia yesterday presented Mary her resignation

(19) (ktes) ipevale i Maria tin peretisi tis yesterday submitted Mary-nom her resignation

On the other hand, Italian does not permit VSO orders at all: *Ieri ha dato Gianni un libro a Maria yesterday has given John a book to Mary (Zubizarreta 1998)

In Italian only VS and VOS orders are allowed, both, however, being subject to a number of restrictions (see below):

(21) a. e arrivato Gianni is arrived John 

b. ?ha mangiato la mela Gianni
has eaten the apple John

Let us now consider in some detail how these word orders, especially the inverted ones, reflect discourse information and whether the type of information associated with the various word order patterns is equivalent in the languages under consideration. ${ }^{4}$

\section{Word Order Patterns and their Sensitivity to Information Structure}

\subsection{SVO in Italian does not constitute aTtopic-Comment structure}

A survey of the literature reveals that there are important differences among the various word patterns in these three NSLs. Importantly, Italian SVO orders seem to have the information structure properties of Greek and Spanish VSO orders. That is, in Italian SVO orders can function as replies to the question 'what happened?' (see (22) from Calabrese 1992).

- what happened?

$$
\begin{aligned}
& \text { Carlo ha presentato Sandro a Maria } \\
& \text { Carlo has presented introduced to Mary } \\
& \text { 'Carlo introduced Sandro to Mary' }
\end{aligned}
$$

(22) clearly shows that preverbal subjects in Italian do not constitute 'old' information. This correlates with the syntax of preverbal subjects in this language, according to which these do not necessarily behave as $\mathrm{A}^{\prime}$-elements (see (12) above).

This is not the case for Greek and Spanish. Only VSO orders can be understood as answers to the question "what happened" in these two languages (see Comorovski 1991, Anagnostopoulou 1994, Zubizarreta 1994). SVO orders are unacceptable in these contexts (cf. 2, repeated below).

- what happened?
a. molis espase o Janis tin kristalini lamba just broke the-John-NOM the crystal lamp 'John just broke the crystal lamp'
b. *molis o Janis espase tin kristalini lamba

An interesting fact about Italian inverted orders is that in this language postverbal subjects with intransitive verbs are also restricted. Consider the examples in (24). Inverted orders are licit with unaccusative predicates, while they are impossible with unergative ones (24b):

-what happened?

\footnotetext{
4 Sources: for Italian: Belletti (1998), Calabrese (1992), Pinto (1997), Zubizarreta (1998). For Spanish: Zubizarreta (1998).
} 

a. e arrivato Gigi is arrived Gigi
b. *ha riso Gigi has laughed Gigi
(Zubizarreta 1998)

Pinto (1997) has argued that constructions of the type in (24a) involve a covert or an overt locative. The locative remains implicit if it is interpreted deictically. Thus a sentences like (24a) means that Gigi arrived here. Evidence for the presence of a covert locative in these contexts comes from a range of facts discussed in Manzini and Savoia (in preparation). Manzini \& Savoia provide data from northern Italian dialects in which VS constructions include both an expletive nominative clitic and a locative clitic, as illustrated in (25) below:
$\mathrm{u}$ ie mwera y galinne. expl loc dies chickens
Montaldo (cited in Zubizarreta 1998: 192)
'Chickens die'

The constraint on VS orders in Italian under the presentational focus interpretation seems to be similar to the constraint encountered in the English locative inversion construction, as shown in (26) (from Levin and Rappaport 1995: 222):

(26) a. In the distance appeared the towers..

b. *In the nursery smile half a dozen newborn babies

Both Italian VS and English locative inversion constructions are grammatical with unaccusative, but not with unergative predicates.

\subsection{The Influence of Aspect}

Horvath (1985) has observed that preverbal or postverbal placement of arguments has an influence on the aspectual interpretation of the sentence. This is particularly clear in Hungarian where sentences are vague with respect to progressive vs. perfective aspect, the actual interpretation depending on the context. Clauses with a V-complement occurring in the pre-V node are interpreted as having perfective Aspect, while clauses in which a complement has been postposed are interpreted as having progressive Aspect. This is illustrated in the examples below:

a. Mari az asztalra rakta az edényeket

Perfective Mary the table-onto piled the dishes

'Mary has piled the dishes on the table'

b. Mari rakta az asztalra az edényeket Mary piled the table-onto the dishes

Progressive

'Mary was piling the dishes on the table'

To account for this state of affairs Horvath proposes a set of template like interpretive rules for the specification of Aspect in Hungarian. Although Horvath assumed that this a phenomenon particular to Hungarian, it turns out that word order is very sensitive to the aspectual properties of verbs across languages and that it crucially interferes with information structure. In what follows I turn to certain aspectual restrictions with the 
VSO/VOS orders in Spanish and Greek, which will actually further support the view that SVO in these languages constitutes a topic-comment structure.

As the data in (28) show, inverted orders in Greek are not acceptable with stative predicates, unless either perfective Aspect is used on the verb (29a) or the verb itself is focussed (29b). On the other hand, inverted orders are grammatical with eventive predicates, as has been illustrated throughout this paper:

a. ${ }^{*}$ misi/agapai/fovate/kseri i Maria ton Petro
hates/loves/fears/knows the-Mary-nom the-Peter-acc

b. *misi ton Petro i Maria

hates the Peter-acc the Mary-nom

vs. c. pandreftike o Petros tin Ilekrta

married the-Peter-nom the-Ilektra-acc

'Peter married Ilekrta'

d. i Maria misi/agapai/fovate/kseri ton Petro

the-Mary-nom hates/loves/fears/knows the-Peter-acc
a. misise/agapise
i Maria
ton Petro
hated-perf-3sg/loved-perf-3sg the-Mary-nom the-Peter-acc

b. KSERI o Janis Germanika

knows-3sg John-nom German-acc

Note that in (29a), however, the meaning of the verb changes: "loved" is understood as "fell in love" (episodic reading).

On the basis of the above data, we can formulate the following generalization (see also Zubizarreta 1994):

\section{Generalization:}

Only non-stative stage level-predicates can appear in inverted orders in Greek and Spanish.

(30) expresses the intuition that the tense/aspect properties of the predicate interact with the discourse function of the construction which is related to presentational focus in an important way. Recall that inverted orders are associated with presentational focus. Statives cannot appear as answers to the question "what happened", as they are inherently incompatible with these contexts. Generic sentences are also expected to be excluded: they correspond to categorical judgements, they are non-stage level (cf. Kuroda 1972, Ladusaw 1993). In fact, this prediction is borne out, as the following examples show. Generic readings are suppressed under VSO (cf. $31 \mathrm{a}$ vs. $31 \mathrm{~b}$ from Alexiadou \& Anagnostopoulou 1995):
a. I gata kinigai pondikia
generic
the-cat-nom chases mice-acc
'Cats chase mice' or 'The cat chases mice'
b. kinigai i gata pondikia
cannot be generic
chases the-cat-nom mice-acc
'The cat chases mice' 
The Greek examples in (31) are strongly reminiscent of Japanese generic sentences which always have the topic marker $w a$ as shown in (32). The presence of a different marker (i.e. the nominative marker $g a$ ) forces a non-generic interpretation. Greek differs from Japanese in that it expresses the same distinction with the choice of a specific word order:
a. Inu wa hasiru
Dogs TOP run
'Dogs run'
b. Inu wa neko o oikakeru
Dogs TOP cats chase
'Dogs chase cats'
c. Inu ga neko o oikakete iru
'The dog is chasing a cat'

\section{Japanese}

As Alexiadou \& Anagnostopoulou (1995) point out, (28d) above could be analysed as Left Dislocation which is an obligatory process with statives due to the special discourse function associated with VSO orders and the inherent incompatibility of statives with this function. This instance of LD is a process of de-focusing in the sense of Reinhart (1995), necessary to avoid the clash that is produced from the fact that in a language like Greek no DP movement is necessary for reasons of feature checking (see Alexiadou \& Anagnostopoulou 1998) and the discourse function associated with the VSO string. From this point of view, whenever morphologically trigerred movements, such as V-movement which obligatorily applies in NSLs, give rise to "inappropriate" information structures, LD of the subject or the object are expected to apply. Consider further the following example (from Alexiadou \& Anagnostopoulou 1995):

$$
\begin{aligned}
& \text { ton Petro ton misi/agapai/fovate i Maria } \\
& \text { the-Peter-acc cl-acc hates/loves/fears the-Mary-nom } \\
& \text { 'Peter Mary hates/loves/fears' }
\end{aligned}
$$

In (33), left dislocation of the object has applied. The structure is as acceptable as (27d) is and they both contrast with (28a).

The examples in (29) showed another interesting property of inverted orders. Whenever a stative predicate surfaces with perfective Aspect or it is focussed, the ungrammatical VSO orders become grammatical again. Kiss (1987) observes that in Hungarian Focus and Aspect marking are in complementary distribution, i.e. if a Hungarian sentence is syntactically marked for Aspect, for instance by containing the adverbial $\mathrm{fel}$ 'up', which triggers a perfective interpretation, then it cannot contain a Focus. If it contains a Focus, then it cannot be syntactically marked for Aspect. The fact that the two elements are mutually exclusive suggests that they share some common grammatical property. That there is a link between Aspect and Focus has also been suggested elsewhere in the literature (see for instance Zubizarreta 1994 and references therein) and the facts discussed here also point to the same direction.

Turning to Italian, Calabrese (1992) points out that VOS orders are acceptable only if they have a telic interpretation, i.e exactly like the Greek VSO and VOS patterns the Italian inverted contruction is sensitive to aspect. This is illustrated in the examples below. As (34) shows, stative predicates are not acceptable in VOS orders (34b), and neither are eventive predicates bearing imperfective morphology. Given that it has been 
argued that imperfective aspect creates stativity readings, it is not unexpected that eventive predicates inflected for imperfective aspect, are unacceptable in the VOS order, exactly like stative predicates.
a. *scriveva una lettera Maria was writing a letter Mary
b. *ama un cavallo Caligola loves a horse $\mathrm{C}$.
Imperfective Aspect
c. *conosce una lingua straniera Sandro knows a language foreign Sandro

\author{
Stative Predicates
}

Note that Italian VOS sentences seem to be sensitive to a heaviness constraint (35a), ${ }^{5}$ which diseappears, together with the aspectual restrictions, once the object has been topicalized (35b) or the subject carries heavy pitch or is metrically branching, as shown in $(35 \mathrm{c} \& d):^{6}$
a. ?ha mangiato la mela Gianni has eaten the apple John
b. la mela, l'ha mangiata Gianni the apple it has eaten John (Zubizarreta 1998)
c. ha mangiato la mela solo Gianni
has eaten the apple only John

\section{d. ha mangiato la mela GIANNI} has eaten the apple John

The pattern in (35) is very similar to the Greek cases discussed earlier on. (35b) can be interpreted as a process of de-focusing in the sense of Reinhart (1995). A similar function is obtained with the focussing of the predicate or of the subject. In other words, the presence of a focus operator in the sentence creates a contrastive focus domain, which necesserily involves movement at LF to an $\mathrm{A}^{\prime}$-position.

There is, however, a difference between VOS orders in Italian and inverted orders in Greek. For most Italian speakers VOS orders have a contrastive focus interpretation on the subject (cf. Belletti 1998), which is not the case for the Greek VOS orders. The latter ones tend to involve new information on the subject. This is illustrated in the examples below. While in (36) the subject is interpreted as contrastively focussed, as signalled by the fact that it can be contrasted with a set of alternatives, this is not the interpretation the subject receives in the Greek VOS order. For the subject to receive a contrastive interpretation in Greek, it has to be fronted (38):

5 Reminiscent of:

(i) a. there hits the stand a new journal

b. there entered the room a man from England

$$
\text { (Chomsky } 1995 \text { citing Kayne) }
$$

6 According to Calabrese, this offers an explanation for the fact that a postverbal subject must be always focalized unless there is a special telic interpretation that provides a spatio-temporal argument that can qualify as the subject of predication. In this sense Italian VOS are similar to the English examples presented in the previous footnote. 
*agorase to isitirio mono i Maria;

bought the ticket-acc only Mar-nom

dil. den agorase to isitirio o Janis

that is neg bought the ticket-acc John-nom

(mono o Janis) agorase to isitirio

only John bought the ticket

(39) provides further evidence for the link between subjects in the VOS order in Greek and presentational focus. As the contrast in the sentences below shows, in a context where only the subject 'a boy' is introduced as 'new' information, then the (39a) may be followed by (39b), but (39c) or (39d) seem very odd. According to my intuitions, (39b) is even better when the object is clitic-doubled. As Anagnostopoulou (1994) has extensively argued, clitic-doubling in Greek is linked to the notion of familiarity in the sense that clitic-doubled objects are 'strong'/'presuppositional'. And indeed the object has already been introduced in the discourse in (39a).

(39) a. O Petros agorase ena vivlio. ke meta

Peter-nom bought-3sg a book. and then

'Peter bought a book. And then

b. (to) katestrepse to vivlio ena agori

cl-acc destroyed-3sg the book-acc a boy-nom

'A boy destroyed the book

c. \%(to) katestrepse ena agori to vivlio

cl-acc destroyed-3sg a boy-nom the book-acc

d. \%ena agori katestrepse to vivlio

a boy-nom destroyed the book-acc

Spanish VOS orders can also involve contrastively focused subjects, but not exclusively as Zubizarreta points out:

(40) solo ha terminado el trabajo MARIA;

only has finished the work Mary;

os sea no ha terminado el trabajo Juan

that is, has not finished the job Juan

Summarizing, in this section the following points have been discussed. Inverted orders (VS/VSO) are in principle presentational contexts. As such they are sensitive to the aspectual properties of the predicate. The aspectual properties are overriden, once one of the elements receives contrastive focus (and exhaustivity readings) or LD of one of the arguments applies. VOS orders in Italian and Spanish, but not in Greek can involve contrastive focus on the subject.

In the next section I show that these differences reflect a difference in the structure of the inverted orders in these three languages. 


\section{Interaction of Information Structure, Prosody and Syntactic Movement}

As has been mentioned in sections 1 and 2, presentational contexts involve arguments in their base position (Greek and Spanish VSO, Italian VS) or maximally as high as TP/AgrSP (Italian SVO). In section 3 it was pointed out that LD of arguments standardly involves movement to or base generation in a position higher than TP/AgrSP, in case an A'-position. The resulting structures are not presentational. The intuition I will pursue here is that generally movement above $\mathrm{T}^{\circ} / \mathrm{TP}$, which destroys the presentational information structure, takes different shapes in the languages under discussion.

Let us first consider the derivation of VOS in Spanish and Greek (cf. Ordoñez 1994, Alexiadou 1997, Zubizarreta 1994). On the basis of data such as the ones presented in (41), where a quantifier contained within the object can bind into the pronominal included within the postverbal subject, Alexiadou (1999) for Greek and Ordoñez (1994), Zubizarreta (1994) for Spanish have argued that the object is located in a specifier position higher than the subject. The object is found in this position as the result of leftward movement over the subject that remains in situ, as shown in (42):

a. sinodepse to kathe pedi i mitera tu accompanied the every child-acc the mother-nom his 'Its mother accompanied every child to school'

b. *sinodepse to pedi tis i kathe mitera accompanied the child-acc hers the every mother-nom

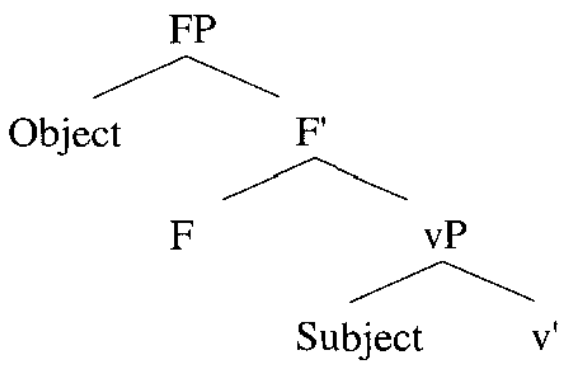

Both Alexiadou (1999) and Zubizarreta (1998) note that this type of scrambling is different from the Germanic type, as it is not restricted to specific DPs. ${ }^{7}$
a. no trajo nada Juan
not brought anything John
Spanish
b. diavase kati
o Janis
Greek
read something-acc John-nom

Given that the grammaticality judgements with respect to the aspectual restrictions are not amended in Greek VOS orders (see the discussion in the previous section), this type of movement is not an instance of LD, but rather an instance of A-movement, as is also manifested by the binding facts in (41). Rather Greek VOS orders behave as presentational in the broad sense: they introduce less familiar information in the context of more familiar information (cf. Levin \& Rappaport 1995).

7 As Costa (1999) points out this does not hold for Portuguese VOS orders, which are sensitive to the definiteness of the object. 
For Spanish, Zubizarreta has extesively argued that this movement is an instance of prosodically motivated movement. That is it applies in cases where the nuclear stress rule and the focus prominence rule give rise to a prosodically contradictory output. In this case, the subject is marked as [+focused]. However, the nuclear stress rule would assign prominence to the object, since this is the most deeply embedded constituent in the VP. As a result, material that is marked [-focused] must leave the VP, so that the most deeply embedded constitent can receive nuclear stress. ${ }^{8}$ In Greek, however, the VOS order is not interpreted with contrastive focus on the subject. But presentational focus receives stresis as well. If this is so, then the movement of the object in Greek could be argued to be prosodically motivated too, although the resulting information structures differ in the two languages.

On the other hand, a different derivation must be assumed for VOS in Italian on the contrastive reading. ${ }^{9}$ Recall that there is a crucial difference between Italian and Greek. Italian behaves like an SVO language with the implication that SpecTP (or the EPP position in general) needs to be filled necessarily, either by a locative or by a DP subject (see also Zubizarreta 1998: 123). If subjects generally A-move to Spec,TP, then a contrastive focus interpretation in this language cannot be the result of an in-situ interpretation. As Samek-Lodovici (1998) points out, contrastive focus in Italian occurs always aligned with the right edge of the sentence. Samek-Lodovici (1995) brings a number of arguments suggesting the subject has $\mathrm{A}^{\prime}$-properties under the contrastive focus interpretation. These arguments come form an examination of binding properties and Weak Crossover (WCO) effects. Consider the examples in (44a) below. The subject is a quantifier phrase raised into Spec,IP from the embedded clause. Since Spec,IP is an A-position and it ccommands the matrix VP, it can bind the pronoun in the indirect argument of the matrix when this reconstructs at LF. The sentence therefore allows for an operator-variable reading where the pronoun is bound by the subject quantified phrase. Compare now (44a) to (44b). According to Samek-Lodovice, if the focus position were an A-position, (44b) should be indistinguishable from (44a) binding-wise and should be grammatical under

8 According to Zubizarreta (1998: 142f.) p-movement does not affect quantifier binding relations. She points out that in Spanish the same quantifier binding relations are found in VSO and VOS orders. Consider the following examples:

(i) a. el primer día de escueala acompañara su MADRE a cada niño the first day of school will-accompany his mother acc every child

b. el primer día de escueala acompañara a cada niño su madre the first day of scholl will-accompany acc every child his mother

In Greek (ia) is ungrammatical, unless the object is clitic-doubled:

(ii) tha *(to) sinodepsi i mitera tu to kathe pedi
fut cl-acc accompany his mother the every child

As Alexiadou \& Anagnostopoulou (2000) point out doubling of object affects binding possibilities, and has the immediate effect that the object is interpreted in a higher position than its base one. Note, however, that there is a crucial difference between (ia) and (ii). The VSO order in Spanish involves constrastive focus on the subject, something which is not possible in Greek, at least according to my intuitions. Thus presumably the structure representation of the two examples differs.

9 According to Cardinaletti (1997), who builds on Ordoñez (1994, 1997), there is evidence that in VOS orders the object undergoes leftward movement to a position higher than the subject. As (i) below shows in Italian a quantificational object can bind a pronoun contained within the subject in the VOS orders:

(i) ha visitato [ogni soldati]i suaj madre

has visited every soldier his mother

'*His mother has visited every soldier'

However, these judgements are not shared by all speakers. In fact as Cecilia Poletto (personal communication) points there is strong variability depending on the type of quantifier. 
the same operator-variable interpretation. Instead (44b) is ungrammatical. Its ungrammaticality follows from the $A^{\prime}$-status of the focus position. In fact, being an $A^{\prime}$-position, the quantified subject cannot bind the pronoun at S-structure. Its $\mathrm{A}^{\prime}$-status forces it to reconstruct at $\mathrm{LF}$ before quantifier raising. When it quantifier raises at $\mathrm{LF}$, it raises past the reconstructed indirect object, creating a WCO violation.

(44) a. ai suoi genitori, ogni bambino e sembrano mangiar poco

[ai suoi $i_{i}$ genitori $]_{k}$, [IP [ogni bambino $]_{i}$ e [vpsembrato $t_{k}\left[t_{i}\right.$ mangiare poco]]]

to his parents, each child is seemed to eat little

b. *ai suoi genitori, e sembrano mangiar poco ogni bambino

[ai suoi $i_{i}$ genitori $]_{k}$, [IP $\mathrm{e}$ [vP[vPsembrato $t_{k}$ [IP $t_{i}$ mangiare poco]] [ogni bambino $\left.]_{i}\right]$ 'EACH child seemed to eat little to his parents' Samek-Lodovici 1995: 15

There are a number of ways to arrive at such a configuration. According to SamekLodovici, the position in question is not the base position of the subject, but a position right adjoined to the IP. Recently Ordoñez (1997), Belletti (1998), Zubizarreta (1998) among others propose that VOS orders in Italian are best analysed as involving movement in several steps (see 45). The first step involves movement of the subject to TP. The second step involves movement of the subject to a focus position. Subsequent steps involve movement of the remnant VP/TP to a position higher than FocusP.

$$
\text { [XP [TP ha mangiato la mela] } \left.\left.\mathrm{X}^{\circ}[\mathrm{FP} \text { Gianni TP }]\right]\right]
$$

Note that the presentational reading, if present at all in the VOS order, could be seen as involving an empty locative in TP, $\mathrm{V}$ movement to $\mathrm{T}$ and Obj movement above the subject to a domain below $\mathrm{T}$, the subject remaining in situ (similarly to the few cases of English Transitive expletive constructions presented in footnote 4). Alternatively, it could be argued that the subject moves to TP and the whole remnant $\mathrm{vP}$, the verb together with the object adjoins to TP, and thus the structure still remains sensitive to the aspectual restrictions, as it is not situated above TP (see 46).

\section{[TP [vP ha mangiato la mela] [TP Gianni vP ]]}

Note here that a number of constructions indicate that such a derivation is not possible for the Greek VOS orders (diagnostics based on Costa 1999 who makes this point for Portuguese VOS orders). As Costa points out, if VOS orders involved movement of the subject and remnant movement of the VP to its left, it would be predicted that floating quantifiers should appear inside the moved constituent, assuming that floating quantifiers are possible after subject movement to Spec,IP (see Sportiche 1988). In fact they don't. This suggests that the analysis of VOS in terms of scrambling is superior; given that the subject remains in situ, floating quantifiers are not predicted to be grammatical in such examples:

(47) a. *ehun diavasi ola to vivlio ta pedia have read all the book the children

b. *ehun ola diavasi to vivlio ta pedia have all read the book the children

c. ehun diavasi to vivlio ola ta pedia have read the book all the children 
Interestingly the equivalent of (46)-(47) in Italian also gives deviant results (Paola Monachesi personal communication), although perhaps the ungrammaticality is not as sharp as in Greek:

(48) a. ??hanno letto tutti il libro i ragazzi

b. ??hanno tutti letto il libro i ragazzi

c. tutti i ragazzi hanno letto il libro

If it turns out that the Italian data are much better than the Portuguese and Greek ones, then this strongly suggests that VOS in Italian truly involves TP movement to a position in the left periphery. The topic awaits further research.

\section{Conclusion}

In this paper I examined certain aspects of word order in three NSLs and how these interact with information structure. I pointed out that although the languages under consideration are thought of as being very similar, one can observe important differences among them both in the preverbal and the postverbal domain. I have argued that these patterns follow from differences in the clausal structure of these languages and the different derivations that underlie them.

\section{References}

Alexiadou, A. 1996. 'Aspectual Restrictions on Word Order'. Folia Linguistica XXX: 36-46.

Alexiadou, A. 1997. Adverb Placement: a case study in Antisymmetric Syntax. John Benjamins.

Alexiadou, A. 1999. 'On the properties of some Greek word order patterns'. In A. Alexiadou, G. Horrocks and M. Stavrou (eds), Studies in Greek Syntax. Kluwer Academic Publishers, 45-65.

Alexiadou, A. \& E. Anagnostopoulou. 1995. SVO and EPP in Null Subject Languages and Germanic. In FASPIL 4: 1-21.

Alexiadou, A. \& E. Anagnostopoulou. 1998. Parametrizing Agr: word order, verb- movement and EPPchecking. Natural Language and Linguistic Theory 16.3: 491-539.

Alexiadou, A. \& E. Anagnostopoulou. 1999. 'Clitic phenomena and (non-) configurationality. Submitted to D. Jung and J. Helmbrecht (eds) Pronominal Arguments: Morphology and Syntax. John Benjamins.

Alexiadou, A. \& E. Anagnostopoulou. 2000. 'Clitic Doubling and Non-configurationality'. In the Proceedings of NELS 30 (papers from the poster session).

Alexiadou, A. \& E. Anagnostopoulou. To appear. Greek Syntax: a Principles and Parameters Perspective. Journal of Greek Linguistics.

Anagnostopoulou, E. 1994. Clitic Dependencies in Modern Greek, unpublished Ph. D. Dissertation, University of Salzburg.

Anagnostopoulou, E. 1999. 'On Experiencers'. In A. Alexiadou, G. Horrocks, and M. Stavrou (eds) Studies in Greek Syntax. Kluwer, pp. 67-93.

Barbosa, P. 1994. 'A new Look at the Null Subject Parameter', Paper presented at CONSOLE III, Venice.

Belletti, A. 1998. 'VSO vs. VOS: On the licensing of possible positions for postverbal subjects in Italian and Romance'. Paper presented at the workshop on Inversion, May 1998, Amsterdam.

Bobaljik, J. and D. Jonas. 1996. 'Subject Positions and the Role of TP', Linguistic Inquiry 27, 195-236.

Calabrese, A. 1992. 'Some Remarks on Focus and Logical Structures in Italian'. Harvard Working Papers.

Canac-Marquis, R. 1991. 'On the Obligatory Character of Inversion in Spanish'. Proceedings of WCCFL 10, 309-318.

Cardinaletti, A. 1997. 'Subjects and Clause Structure'. In L. Haegeman (ed.) The New Comparative Syntax. Longman.

Cinque, G. 1990. Types of $A^{\prime}$-Dependencies, MIT Press, Cambridge: Mass.

Comorovski, I. 1991. "Partitives and the Definiteness Effect". Proceedings of NELS 10, 91-102. 
Contreras, H. 1991. 'On the Position of Subjects', in S. Rothstein (ed.), Perspectives on Phrase Structure: Heads and Licensing, Syntax and Semantics 25, Academic Press, San Diego, pp. 63-79.

Costa, J. 1998. Word Order Variation: a Constraint based approach. Doctoral dissertation, Leiden.

Costa, J. 1999. 'VOS in Portuguese: arguments against an analysis in terms of remnant movement'. Paper presented at the Workshop on Remnant Movement, Feature Movement and their Implications for the T-model'. Potsdam July 1999.

Diesing, M. 1992. Indefinites. Cambridge, Mass.: MIT Press.

Dobrovie-Sorin, C. 1987. Syntaxe du Roumain, unpublished These de Doctorat d'Etat, Universite de Paris 7.

Dobrovie-Sorin, C. 1990. 'Clitic Doubling, Wh Movement and Quantification in Romanian'. Linguistic Inquiry 21 .

Giannakidou, A. 1997. The Landscape of Polarity Items. Doctoral dissertation, University of Groningen.

Horvath, J. 1985. FOCUS in the Theory of Grammar and the Syntax of Hungarian. Dordrecht: Foris.

Kiss, K. 1987. Configurationality in Hungarian. Akademiai Kiado, Budapest.

Kiss, K. 1995. Introduction. In K. Kiss (ed.) Discourse Configurational Languages. Oxford University Press, 3-27.

Kuroda, S.Y. 1972. 'The categorical and the thetic judgement' in Foundations of Language 9: 153-185.

Ladusaw, W. 1994. 'Thetic and Categorial, Stage and Individual, Weak and Strong' in Proceedings of SALT IV 220-229.

Levin, B \&. M. Rappaport-Hovav. 1995. Unaccusativity. MIT Press.

McCloskey, James. 1996. 'Subjects and Subject Positions in Irish', in B. Borsley and Ian Roberts (eds.), The Syntax of Celtic Languages, Cambridge University Press, Cambridge, pp. 241-283.

Meinunger, A. 1999. Syntactic Aspects of Topic and Comment. To appear Amsterdam: John Benjamins.

Ordoñez, F. 1994. 'Post-verbal Asymmetries in Spanish', paper presented at the Vienna GLOW Colloquium.

Ordoñez, F. 1997. Word Order and Clause Structure in Spanish and other Romance languages. Ph. D. dissertation, CUNY.

Ortiz de Urbina, J. 1995 'Residual Verb Second and Verb First in Basque'. In K. Kiss (ed.) Discourse Configurational Languages. Oxford: Oxford University Press, pp. 99-121.

Reinhart, T. 1995. Interface Strategies. OTS.

Rochemont, M. 1986. Focus in Generative Grammar. Amsterdam: John Benjamins.

Samek-Lodovici, V. 1995. 'Italian's focus position'. Ms., Ruttgers University.

Samek-Lodovici, V. 1998. 'When Preverbal Focus is Clause-final: a unified analysis of contrastive focus in Italian'. Paper presented at the Workshop on Inversion in Romance, Amsterdam, May 1998.

Sportiche, D. 1988. 'A Theory of Floating Quantifiers and its Corollaries for Constituent Structure'. Linguistic Inquiry 19, 425-449.

Torrego, E. 1984. 'On Inversion in Spanish and Some of its Effects', Linguistic Inquiry 15, 103-129.

Tsimpli, I.M. 1995. 'Focussing in Modern Greek'. In K. Kiss (ed.) Discourse Configurational Languages. Oxford University Press, 176-206.

Zubizaretta, Maria-Luisa. 1994. 'Grammatical Representation of Topic and Focus; Implications for the Structure of the Clause' Cuademos de Linguistica del I.U. Ortega y Gasset. 2, 181-208.

Zubizarreta, M.L. 1998. Prosody, Focus and Word Order. MIT Press. 